\title{
A Case Study on Electricity Consumption and Value Engineering in a Tertiary Care Hospital
}

\author{
Zuber Mujeeb Shaikh \\ Director, Corporate Quality Improvement, \\ Dr. Sulaiman Al Habib Medical Group Holding Company, \\ Riyadh-11643, Kingdom of Saudi Arabia \\ Email-drzuber5@yahoo.co.in
}

Type of the Paper: Case Report.

Type of Review: Peer Reviewed.

Indexed In: OpenAIRE.

DOI: https://doi.org/10.5281/zenodo.3411846.

Google Scholar Citation: IJHSP

\section{How to Cite this Paper:}

Shaikh, Zuber Mujeeb. (2019). A Case Study on Electricity Consumption and Value Engineering in a Tertiary Care Hospital. International Journal of Health Sciences and Pharmacy (IJHSP), 3(2), 11-15. DOI: https://doi.org/10.5281/zenodo.3411846.

International Journal of Health Sciences and Pharmacy (IJHSP)

A Refereed International Journal of Srinivas University, India.

IFSIJ Journal Impact Factor for 2019-20 = 3.968

(C) With Author.

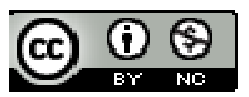

This work is licensed under a Creative Commons Attribution-Non Commercial 4.0 International License subject to proper citation to the publication source of the work.

Disclaimer: The scholarly papers as reviewed and published by the Srinivas Publications (S.P.), India are the views and opinions of their respective authors and are not the views or opinions of the SP. The SP disclaims of any harm or loss caused due to the published content to any party. 


\title{
A Case Study on Electricity Consumption and Value Engineering in a Tertiary Care Hospital
}

\author{
Zuber Mujeeb Shaikh \\ Director, Corporate Quality Improvement, \\ Dr. Sulaiman Al Habib Medical Group Holding Company, \\ Riyadh-11643, Kingdom of Saudi Arabia \\ Email-drzuber5@yahoo.co.in
}

\begin{abstract}
This Case Study compares the consumption of electricity in a Tertiary Care Hospital before and after the implementation of Value Engineering/ Value Analysis (VE/VA). In this study we provided the training, education, assigned responsibilities, conducted brainstorming sessions and the control mechanism to the concerned staff for the control of the consumption of electricity in the hospital with premises while maintaining the quality of service by replacing the incandescent bulbs with compact fluorescent light bulbs in the corridors. Methodology: This is Case Study method in which we have used the direct observation and personal interview methods for primary data and secondary data collected from the published research papers and journals. Conclusion: The Organization saved 1, 32,810 Rupees per month after the implementation of VA/ VE Concept.
\end{abstract}

Keywords: Value Engineering, Value, Electricity Consumption.

\section{INTRODUCTION :}

L.D. Miles definition of VE- "It is a creative approach which has for its purpose the efficient identification of unnecessary cost, i.e. cost which provides neither quality, nor use, nor life, nor appearance, nor customer features" [1]. Value Analysis/ Value Engineering is a systematic application of established techniques to identify the functions of a product (service, system) or component and to provide the desired functions at the lowest total cost. It is a creative approach to eliminating unnecessary costs which add neither to quality nor to the appearance of the product [2].

A survey by the Hosmac India Private Limited revealed that hospitals in Mumbai spend the most in terms of electricity consumed per bed a day- about Rs 483 as compared to the hospitals in other cities. According to the survey, high-tech hospitals spend more on electricity [3]. The eleventh five-year plan aims to conserve 10,000 MW of power, through various energy efficient technologies. One report estimates that hospitals in India spend Rs 1,000 crore every year to meet their energy demands. This is expected to double in the next three years [4]. In South Africa the Netcare Ferncrest Hospital technical services team reduced their consumption by $46.8 \%$ by managing air-conditioning, water heating and lighting, a remarkable reduction achieved without affecting patient comfort or business processes [5]. In UK the hospital staff are being banned from making cups of tea because bosses want to cut down on electricity, as in a hospital, electricity costs are going to be high because of lighting and heating [6].

In 2003 the engineering departments of our Binghamton-area hospitals, under the leadership of John Carrigg, Vice-President of Operations, avoided $\$ 61,000$ in energy consumption costs through good operating practices and energy conservation measures [7]. Electricity consumption in the tertiary sector is still increasing - by $3 \%$ per year between 1995 and 2005 in the EU-25 countries - and a further increase is expected of more than $2 \%$ per year over the next 15 years [8]. Hospitals and hospital buildings everywhere are large consumers of energy, which they use in many different ways. They have a high potential for energy savings, estimated to 
range from 20\% (Germany) up to $44 \%$ (Netherlands) [9].

\section{HISTORICAL PERSPECTIVE :}

Value Engineering had its origin at General Electric Company, under the leadership of L.D.Miles. L.D.Miles wrote the book "Techniques of Value Analysis and Engineering" and he is considered as the Father of Value Engineering. VE is widely used in industry and government, particularly in areas such as Defense, Transportation, Construction and Healthcare.

\section{THE VALUE ENGINEERING CAN HELP A HEALTH-CARE ORGANIZATION BY :}

Lowering operating and maintenance cost, Improving quality management, Improving resource efficiency, Simplifying procedures, Minimizing paperwork, Lowering staffing cost, Increasing procurement efficiency and Optimizing construction expenditure.

A. Value Engineering Phases:

(1) Selection: Selection of the right projects, processes or elements

(2) Investigation: Background information, function analysis, team focus

(3) Speculation: Creative, brainstorming, alternative proposals

(4) Evaluation: Analysis of alternatives, life cycle costs

(5) Development: Develop technical and economic supporting data

(6) Presentation: Present recommendations and team findings

(7) Implementation: Fair evaluation of proposals, implementation plan

(8) Audit: Review of completed results, accomplishments and awards

Value is usually confused with the monetary price or cost of the item. However value is not synonymous with the cost. Value may be perceived as the ratio of the sum of positive and negative aspects of an object.

\section{OBJECTIVES OF THE STUDY :}

(1) To study the electricity consumption during the day and night time in the study hospital and premises.

(2) To compare the electricity consumption after providing the education, training, control and assigning the responsibility.

(3) To recommend and implement VE/ VA to reduce the consumption of electricity while still maintaining the quality.

\section{DISCUSSION AND FINDING :}

The study hospital is a Tertiary Care 250 beds (in the year 2008) Hospital, located in the heart of the city of Secunderabad, Telangana State, India, with eight Operation Theaters, HiTech Radiology Department which provides round the clock Services, Cath Lab, 240 Clinics, MICU, SICU, PICU, NICU, CCU, PACU and Emergency Department. The Hospital is providing Health Care Services to all the classes of population, hence has VIP Suites, Deluxe Rooms, Single Rooms, Sharing Rooms (M/F), General Wards (M/F) and a 24X7 Dialysis Unit. The hospital was designed scientifically to maximize natural lighting and ventilation.

The Hospital has four generators, UPS and Central $\mathrm{A} / \mathrm{C}$ for providing continuous patient services quality.

(A) Study and Implementation of Value Engineering Phases:

(1) Selection: As the study Hospital was paying the huge electricity bill (an average) of twenty Lakhs Indian rupees/ Month, the Electricity Consumption Study was selected to reduce the consumption and thereby the cost without affecting the quality.

(2) Investigation: The consumption of electricity in the study hospital in day time was very high (average 2160 Units) as the hospital has eight Operation Theaters with other Support Departments all of which were running at full capacity; the hospital staff has three working shifts. The Night Shift timings were from $08 \mathrm{pm}$ to $08 \mathrm{am}$. The night shift housekeeping staff was responsible for cleaning all the vacant rooms/ wards, corridors and open spaces in and the premises of the hospital. We observed that after cleaning the vacant rooms and corridors, the staff never switched off the lights, television, or fan control unit of that room, highlighting the lack of responsibility, proper control, training, and experienced manpower.

(3) Speculation: As the Hospital was paying a huge electricity bill per month, the areas where savings in the consumption of electricity in the Hospital were identified.

- Phase-I - Include provision of training, education, responsibility, control and 
brainstorming sessions (January 2007-June 2007).

- Phase-II - Replacement of the existing light bulbs with compact fluorescent light bulbs. CFL uses 75 percent less energy and lasts about 10 times longer than an incandescent bulb. The project team explained and discussed the plans with the engineers and the management to replace the existing 620 incandescent bulbs (100 Watts) with compact fluorescent light bulbs (of 60 Watts) in all the corridors and the hospital premises. In the day all the curtains in the corridors were kept open. All the concerned staff was trained and their supervisors were provided a checklist for their duties. The use of the HVAC Unit and the building lights around the hospital in the night were controlled at night (July 2007-December 2007).

(4) Evaluation: Average Electricity (Elect.) Consumption (Cons.) of the study hospital was (for the year 2006):

Table 1 : Average electricity consumption

\begin{tabular}{|l|l|r|}
\hline Sr.No. & Description (Average) & \multicolumn{1}{c|}{ Values } \\
\hline 1 & $\begin{array}{l}\text { Elect. Unit Consumption } \\
\text { Per Day }\end{array}$ & 2160 \\
\hline 2 & $\begin{array}{l}\text { Elect. Unit Consumption } \\
\text { Per Night }\end{array}$ & 1355 \\
\hline 3 & $\begin{array}{l}\text { Elect. Unit Consumption } \\
\text { in 24 Hours }\end{array}$ & 3515 \\
\hline 4 & Per Unit Charge (INR) & 19 \\
\hline 5 & $\begin{array}{l}\text { Total Elect. Units } \\
\text { Consumption Per Month }\end{array}$ & 105450 \\
\hline 6 & $\begin{array}{l}\text { Electricity Bill Per Month } \\
\text { in Rupees }\end{array}$ & 2003550 \\
\hline
\end{tabular}

(5) Development: The unit price of one CFL bulb was 120 INR. Total estimated cost for replacing 620 incandescent bulbs (100 Watts) with compact fluorescent light bulbs (60 Watts) was Rupees 67, 200. .

(6) Presentation: Observations / Findings were presented to the Management as follows:

- Lack of experienced manpower,

- Lack of training

- Lack of responsibility

- Tardy work behaviour

- Negligence of the support staff in the night shift

- Lack of policies and procedures on electricity utilization (e.g. shut down of the computers/ lights when off duty etc.)

- No Building Management System

- High Tension Transformer was not available

(7) Implementation: The management implemented the VE by implementing the Phase-I and II with necessary changes in the manpower with their maintenance department and other support staff.

8) Audit: Values in the below table depicts the comparative study of the Study Hospital in Phase-I and II.

As mentioned in the above table, the Study Hospital was spending extra Rs.1, 32,810 per month on its electricity bills. After the implementation of the VE/ VA, the hospital saved the same amount per month for use in expanding/ improving other services.

Table 2 : Comparative study of the Study Hospital in Phases

\begin{tabular}{|c|l|c|c|c|c|}
\hline $\begin{array}{c}\text { Sr. } \\
\text { No. }\end{array}$ & \multicolumn{1}{|c|}{ Description } & $\begin{array}{c}\text { Initial } \\
\text { Values } \\
\text { Average of } \\
\text { the year } \\
\text { 2006) }\end{array}$ & $\begin{array}{c}\text { Phase } \\
\text { I }\end{array}$ & $\begin{array}{c}\text { Phase } \\
\text { II }\end{array}$ & $\begin{array}{c}\text { Total } \\
\text { Difference }\end{array}$ \\
\hline 1 & $\begin{array}{l}\text { Elect. Unit Cons. } \\
\text { Per Day }\end{array}$ & 2160 & 2144 & 2114 & 46 \\
\hline 2 & Elect. Unit Cons. Per Night & 1355 & 1318 & 1168 & 187 \\
\hline 3 & $\begin{array}{l}\text { Elect. Unit Cons. } \\
\text { in 24 Hours }\end{array}$ & 3515 & 3462 & 3282 & 233 \\
\hline 4 & $\begin{array}{l}\text { Total Elect. Units Cons. Per } \\
\text { Month }\end{array}$ & 105450 & 103860 & 98460 & 6,990 \\
\hline 5 & $\begin{array}{l}\text { Electricity Bill Per Month in } \\
\text { Rupees }\end{array}$ & 2003550 & 1973340 & 1870740 & 132810 \\
\hline
\end{tabular}




\section{CONCLUSION :}

The Study Hospital started to save Rupees 30210 per month after the implementation of the first stage and Rupees 132810 after the implementation of stage II, and saved total of, Rupees 132,810 per month after the stage I and Stage II.

\section{LIMITATIONS OF THE STUDY :}

This study is limited to the Krishna Institute of Medical Science (KIMS), Secunderabad, Telangana State, India for a limited duration of six months (year 2007-2008) only.

\section{DIRECTIONS FOR FUTURE RESEARCH :}

In future such studies should be conducted to study the electricity consumption at department level of the hospital in order to implement the VA/VE.

\section{SOURCES OF FUNDING FOR THE STUDY :}

This research was self financed by the author himself.

\section{ACKNOWLEDGEMENT :}

The author would like to thank the leadership and all staff of Krishna Institute of Medical Science (KIMS), Secunderabad, Telangana State, India involved in this study. KIMS Hospital is a multi-super Specialty hospital with ISO 9000:2001, NABL and NABH accreditations.

\section{DISCLAIMER :}

This publication contains information obtained from authentic and highly regarded sources. Reasonable effort has been made to publish reliable data and information, but the author and the publisher cannot assume responsibility for the validity of all materials or for the consequences of the use.

All rights reserved. No part of this publication may be reproduced, stored in a retrieval system or transmitted, in any form, or by any means, electronic, mechanical, photocopying, recording or otherwise, without prior permission, in writing, from the publisher or the author.

\section{REFERENCES:}

[1] Miles. Lawrence D. (1982).
Techniques of Value Analysis and Engineering, New York: McGraw Hill, 1982.

[2] Gupta, C. B. (2006). Operations Management and Control, Sultan Chand and Sons, IV Revised and enlarged Edition 2006, New Delhi, page 4.85

[3] Express News Service Tags: Mumbai, hospitals consuming most of the power Posted: Wednesday, Jun 24, 2009, Mumbai.

[4] Deepalakshmi, K. (2001). Energy Management in Hospitals, Express Healthcare Management.

[5] Netcare Annual Report, South Africa, 2007.

[6] Daily Mail Reporter, London, UK, 17th July 2008.

[7] Henry Manczyk, CPE, CEM, Physical Plant Manager, Engineering Department Wilson Memorial Regional Medical Center, Johnson City, NY, Energy Management Strategies In Response To Skyrocketing Energy Costs, November 1, 2004.

[8] Edelgard Gruber, Ilias Sofronis, Rinto Dusée, Stefan Plesser, Detailed analysis of electricity consumption in tertiary buildings as a basis for energy efficiency policies, Summer Study, ECEEE 2007.

[9] Saving Energy with Energy Efficiency in Hospitals, Centre for the Analysis and Dissemination of Demonstrated Energy Technologies, Netherlands, 2005. 